\title{
DETERMINATION OF COMPETENCE, INDIVIDUAL CARACTERISTICS, EDUCATION AND TRAINING ON SATISFACTION WORKING THROUGH THE PERFORMANCE OF EMPLOYEES IN HR DEVELOPMENT AGENCY KARIMUN DISTRICT
}

\author{
Ady Kurniawan ${ }^{1}$, Indrayani ${ }^{2}$, Muammar Khaddafi ${ }^{3}$, Ngaliman $^{4}$ \\ ${ }^{1,2,4}$ Faculty of Economics, Department of Management, University of Batam \\ ${ }^{3}$ Fakultas Ekonomi Universitas Malikussaleh
}

\begin{abstract}
Competency-based HR management is a must, as a paradigm of the approach that is considered the most urgent to emphasize that the human element is the main element of organizational success. However, organizations to be able to provide quality state civil servants in order to support the achievement of the goals and objectives of the organization with high performance standards need to continuously improve the mtu and quality of its human resources. In addition, the competencies possessed by each employee individually can support the implementation of the organization's vision and mission through the strategic performance of government organizations. In this research, the title under study is: Competence Determination, Individual Characteristics, Education and Training on Job Satisfaction through Employee Performance at the Karimun District Human Resources Development Agency.
\end{abstract}

Keywords: Competence, Individual Characteristics, Education and Training, Employee Performance, Job Satisfaction

\section{INTRODUCTION}

Civil servants as human resources who are in the government sector play an important role in the success of the implementation of government administration and national development so that the position and role of civil servants is very important as executors of government activities.

The government then establishes policies related to the human resources of the apparatus to obtain and increase the capacity of professional employees with the quality of employees who are smart, skilled and competent, can work hard, are creative, and have high morality. However advanced technology and other organizational resources, the human factor still plays an important role for the success of an organization.

Apparatus as an important element of government organizations as an important element in the organization, according to Hasibuan (2011: 10), human resource management is the science and art of managing the relationships and roles of the workforce to be effective and efficient, helping the realization of company, employee and community goals.

The human resource management process within the scope of government organizations is carried out in the form of recruitment (procurement), maintenance (maintenance) and development (development). This policy is regulated in Government Regulation PP No. 11/2002 concerning the Procurement of Civil Servants and PP No. 54/2003 concerning Civil Servant Formations and Government Regulation No. 13/2000 concerning the Appointment of Civil Servants in Structural Positions.

As a form of human resource development within the government, it is stated in Law Number 5 of 2014 concerning State Civil Servants (ASN) that the State Civil Apparatus (ASN) is a form of profession which contains logical consequences, namely the importance of principles, basic values, code of ethics and code of conduct, and development. competencies for ASN employees, both Civil Servants (PNS) and Government Employees with Work Agreements (PPKK) (Suyono, 2014). 


\section{DETERMINATION OF COMPETENCE, INDIVIDUAL CARACTERISTICS, EDUCATION AND TRAINING ON SATISFACTION WORKING THROUGH THE PERFORMANCE OF EMPLOYEES IN HR DEVELOPMENT AGENCY KARIMUN DISTRICT}

DOI: https://doi.org/10.54443/ijerlas.v2i1.144

According to Wibowo (2013) competence is the level of skills, knowledge, and behavior possessed by an individual in carrying out the tasks assigned to him in the organization. According to Tagala (2018) competence is a characteristic that underlies the nature of an individual that is linked to the criteria referenced to superior or effective performance in a job or situation. Boulter (in Yunus, 2009) says that competence is a basic characteristic of a person that enables them to produce superior performance in their work.

Competence has a very important role, because it involves a person's basic ability to do a job. Competence is a basic characteristic of a person that indicates how to think, behave and act and draw conclusions that can be done and maintained by a person at a certain time. Competence is seen as a specific attribute, such as knowledge and skills that are used to show a performance in a job that is being done according to Sandberg (in Dewi et al., 2017).

According to Robbins (2012) individual characteristics are the overall behavior and abilities that exist in individuals as a result of their natural environment. Individual characteristics can be measured by attitudes, interests and needs

According to Sumarsono (2009: 93) education and training are important factors in human resource development. Education and training not only increase knowledge, but also increase work skills, thereby increasing work productivity.

The provision of education and training is one of the efforts to improve the quality of human resources according to job requirements. In order to improve human resources in each work unit, it will also be related to the nature of education and training.

According to H.A.R. Tilaar (2008: 16), in a popular sense the terms education and training are distinguished. Training assumes a basic formal education. Training has the connotation of mastering certain skills both physical and mental academic skills required in certain professions. Training is thus linked to the world of work and productivity. On the other hand, education has an orientation towards one's personal development.

According to Rivai (2009) training is a part that concerns the learning process to acquire and improve skills outside the applicable education system in a relatively short time with methods that prioritize practice rather than theory. Education and training is the creation of an environment where employees can acquire or learn specific attitudes, abilities, skills, knowledge and behavior related to work.

Performance appraisal in HR management plays an important role in supporting organizational success. Performance appraisal is one of the most important tasks for a manager or leader to do. According to Dessler (2007) in Widodo (2015) performance appraisal is a key factor in developing an effective and efficient organization. According to Fahmi (2014) performance appraisal is an assessment carried out on company management, both employees and managers who have been doing their job. According to Bacal (2012) in Wibowo (2016) performance appraisal is a process by which individual performance is measured and evaluated. Performance appraisals answer the question, how well are workers performing over a certain period of time

Basically, job satisfaction is an individual thing. Each employee will have a different level of satisfaction according to the value system that applies within him. The more aspects of work that are in accordance with individual desires, the higher the level of satisfaction felt and vice versa. Satisfied employees do a better job at fulfilling the obligations as outlined in the job description. The reality shows that positive feelings encourage creativity, improve problem solving and decision making. Positive feelings also improve task persistence and attract more help and support from colleagues.

Humans in life have basic needs that cannot be eliminated, because these needs underlie one's behavior. If someone at work feels that their needs have been met, then they will have job satisfaction. Job satisfaction is one of the most important elements in an organization. This is because job satisfaction can affect work behavior such as being lazy, diligent, productive, etc., or 
having relationships with several types of behavior that are very important in organizations. For more details, several definitions of satisfaction will be presented.

Job satisfaction is often used as a measure of the maturity level of an organization in modern organizational life. This means that the organization is well managed which is the result of effective management. Satisfaction of various wants and needs of employees will determine their attitude and behavior at work.

\section{IMPLEMENTATION METHOD}

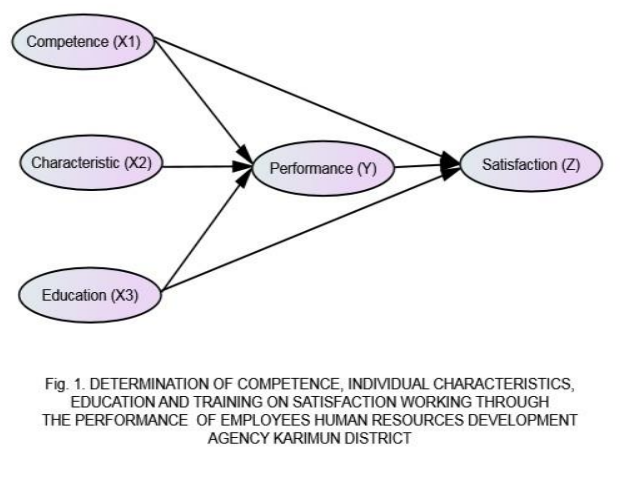

This study aims 1) To determine the determination of competence on employee performance at the HR Development Agency of Karimun Regency. 2) To determine the determination of individual characteristics on the performance of employees at the Karimun Regency HR Development Agency. 3) To determine the determination of education and training on employee performance at the District HR Development Agency. 4) To determine the determination of employee performance on job satisfaction at the Karimun Regency HR Development Agency. 5) To determine the determination of competence on job satisfaction at the HR Development Agency of Karimun Regency. 6) To determine the determination of individual characteristics on job satisfaction at the Karimun Regency HR Development Agency. 7) To determine the determination of education and training on job satisfaction at the Karimun Regency HR Development Agency.

\section{RESULTS AND DISCUSSION \\ Outer Model Evaluation}

Measurement models can show the relationship between manifest variables or measurement items to latent variables present in research, or can be said to be calibration of research instruments. The sub-chapter below will show the results of the measurement model tested with the help of PLS software. These tests include convergent validity tests, discriminant validity tests, and reliability tests.

Based on Table 1. shows that the AVE and communality values of all variables have qualified validity. All items have a loading factor value of more than 0.5. The AVE and communality values of each construct have been more than 0.5 . This indicates that all items on each construct can be declared valid. All construct variables have cronbach's alpha value and composite reliability of more than 0.6 . The conclusion is that all the variable constructs used in this study have tested reliability tests or can be said to be reliable. 
Volume 2 Issue 1 (2022)

DETERMINATION OF COMPETENCE, INDIVIDUAL CARACTERISTICS, EDUCATION AND TRAINING ON SATISFACTION WORKING THROUGH THE PERFORMANCE OF EMPLOYEES IN HR DEVELOPMENT AGENCY KARIMUN DISTRICT

DOI: https://doi.org/10.54443/ijerlas.v2i1.144

Table 2. Convergent Validity and Reliability Values

\begin{tabular}{|c|c|c|c|c|}
\hline Indicator & Loading & AVE & $\begin{array}{c}\text { Cronbach } \\
\text { alpha }\end{array}$ & $\begin{array}{l}\text { Composite } \\
\text { reliability }\end{array}$ \\
\hline $\mathrm{X} 1.1$ & 0.670 & \multirow[t]{6}{*}{0.738} & \multirow[t]{6}{*}{0.827} & \multirow[t]{6}{*}{0.893} \\
\hline $\mathrm{X} 1.2$ & 0.695 & & & \\
\hline $\mathrm{X} 1.3$ & 0.949 & & & \\
\hline $\mathrm{X} 1.4$ & 0.941 & & & \\
\hline $\mathrm{X} 1.5$ & 0.885 & & & \\
\hline X1.6 & 0.830 & & & \\
\hline $\mathrm{X} 2.1$ & 0.756 & \multirow[t]{3}{*}{0.698} & \multirow[t]{3}{*}{0.910} & \multirow[t]{3}{*}{0.932} \\
\hline $\mathrm{X} 2.2$ & 0.914 & & & \\
\hline $\mathrm{X} 2.3$ & 0.899 & & & \\
\hline X3.1 & 0.920 & \multirow[t]{6}{*}{0.776} & \multirow[t]{6}{*}{0.942} & \multirow[t]{6}{*}{0.954} \\
\hline X3.2 & 0.904 & & & \\
\hline X3.3 & 0.837 & & & \\
\hline X3.4 & 0.921 & & & \\
\hline X3.5 & 0.891 & & & \\
\hline X3.6 & 0.805 & & & \\
\hline Y1 & 0.915 & \multirow[t]{4}{*}{0.704} & \multirow[t]{4}{*}{0.857} & \multirow[t]{4}{*}{0.904} \\
\hline $\mathrm{Y} 2$ & 0.889 & & & \\
\hline $\mathrm{Y} 3$ & 0.836 & & & \\
\hline $\mathrm{Y} 4$ & 0.698 & & & \\
\hline $\mathrm{Z1}$ & 0.863 & \multirow[t]{4}{*}{0.719} & \multirow[t]{4}{*}{0.869} & \multirow[t]{4}{*}{0.911} \\
\hline$\overline{\mathrm{Z} 2}$ & 0.817 & & & \\
\hline $\mathrm{Z3}$ & 0.828 & & & \\
\hline$\overline{Z 4}$ & 0.882 & & & \\
\hline
\end{tabular}

\section{Inner Model Evaluation}

Inner Model testing will show the relationship between variables in accordance with theoretical studies as well as support the results of previous research. Inner model analysis can be seen from 3 indicators namely R-Square (R2), Q-Square Predictive Relevance (Q2), and Goodness of Fit (GoF).

Table 3. Inner model evaluation

\begin{tabular}{|l|r|r|r|}
\hline Variables & R Square & Q Square & GoF \\
\hline Performance $(\mathrm{Y})$ & 0.703 & 0.940 & 0.738 \\
\cline { 1 - 2 } Satisfaction $(\mathrm{Z})$ & 0.797 & & \\
\hline
\end{tabular}

Based Ghozali \& Latan (2012), determinant coefficient (R2) value of 0.75, 0.50, and 0,25 is described as a rough rule of thumb for strong, moderate, and weak relationship. These values in table 3 fall into a strong relationship. 
Based Ghozali \& Latan (2012), Q-Square Predictive Relevance (Q2) value of 0.35, 0.15, and 0,02 is described as a rough rule of thumb for strong, moderate, and weak models. Q2 in this study was 0.940 or $94 \%$. This research model is categorized into strong models, meaning that satisfaction variables can be predicted by exogeneous variable, and the rest $(100 \%-63 \%=37 \%)$ is a contribution from other variables not described in this research model.

The result of the calculation above gets a GoF value of 0.738 . In conclusion, the structural model of this research generally has good predictive properties (GoF large) (Ghozali and Latan, 2012), meaning that the model has a high ability to explain empirical data.

\section{Direct Effect Testing and Indirect/ Mediation Effects Testing}

Hypothesis testing is carried out to determine the effect of workload variables on turnover intention, either directly or indirectly through work stress variables and work engagement. The following displays a bosststrapping results summary of the direct influence of independent variables on dependents.

Table 4. Hypothesis testing

\begin{tabular}{|l|l|r|r|r|r|l|}
\hline Hypotesis & \multicolumn{1}{|c|}{ Relat } & Coef. & St. Dev & T-value & & \multicolumn{1}{|c|}{ Description } \\
\hline & \multicolumn{1}{|c|}{ Direct Effect } & & & & & \\
\hline H1 & Competence (X1) -> Performance (Y) & 0.165 & 0.112 & 1.473 & 0.141 & Not Significant \\
\hline H2 & Competence (X1) -> Satisfaction (Z) & 0.172 & 0.079 & 2.188 & 0.029 & Significant \\
\hline H3 & Characteristic (X2) -> Performance (Y) & 0.329 & 0.118 & 2.781 & 0.006 & Significant \\
\hline H4 & Characteristic (X2) -> Satisfaction (Z) & -0.042 & 0.129 & 0.328 & 0.743 & Not Significant \\
\hline H5 & Education (X3) -> Performance (Y) & 0.454 & 0.141 & 3.224 & 0.001 & Significant \\
\hline H6 & Education (X3) -> Satisfaction (Z) & -0.018 & 0.141 & 0.124 & 0.901 & Not Significant \\
\hline H7 & Performance (Y) -> Satisfaction (Z) & 0.821 & 0.154 & 5.323 & 0.000 & Significant \\
\hline & Indirect Effect & & & & & \\
\hline H8 & X1 -> Y -> Z & 0.135 & 0.097 & 1.394 & 0.164 & Not Significant \\
\hline H9 & X2 -> Y -> Z & 0.270 & 0.119 & 2.266 & 0.024 & Significant \\
\hline H10 & X3 -> Y -> Z & 0.373 & 0.140 & 2.671 & 0.008 & Significant \\
\hline
\end{tabular}

Based on table 3, we have conclusion that relationship between variables base on hypothesis in this study is there are 6 (six) hypothesis that can be accept in this study, it is hypothesis 1 , hypothesis 4 , hypothesis 5 , hypothesis 7 , hypothesis 8 , and hypothesis 10 . Then, for other hypotheses namely hypothesis 2 , hypothesis 3 , hypothesis 6 , and hypothesis 9 , it is statistically rejected. it means that the relationship between the two variables is not significant.

\subsection{Discussion Hypothesis 1}

Competence (X1) has a positive and non significant effect on Performance (Y). This result is shown by a positive path coefficient of 0.165 with $\mathrm{T}$ - statistic $=1.473$ ( $\mathrm{T}$ - statistic $<1.96$ ). These results show that hypothesis-1 (H1): competence (X1) has no effect on performance proven empirically. Based on these results can be stated that the higher the competence the employees, the employee performance isn't increasing directly.

\section{Hypothesis 2}

Competence (X1) has a positive and significant effect on satisfaction (Y). This result is shown by a positive path coefficient of 0.172 with $\mathrm{T}$ - statistic $=2.118$ ( $\mathrm{T}$ - statistic $>1.96)$. These results show that hypothesis-2 (H2): competence (X1) has effect on satisfaction proven empirically. 


\section{DETERMINATION OF COMPETENCE, INDIVIDUAL CARACTERISTICS, EDUCATION AND TRAINING ON SATISFACTION WORKING THROUGH THE PERFORMANCE OF EMPLOYEES IN HR DEVELOPMENT AGENCY KARIMUN DISTRICT}

DOI: https://doi.org/10.54443/ijerlas.v2i1.144

Based on these results can be stated that the higher the competence the employees, the employee satisfaction is increasing directly.

\section{Hypothesis 3}

Characteristic (X2) has a positive and significant effect on performance (Y). This result is shown by a positive path coefficient of 0.329 with $\mathrm{T}$ - statistic $=2.781$ ( $\mathrm{T}$ - statistic $>1.96)$. These results show that hypothesis-3 (H2): caracteristic (X2) has effect on performance proven empirically. Based on these results can be stated that the higher the characteristic the employees, the employee performance is increasing directly.

\section{Hypothesis 4}

Characteristic (X2) has a negative effect on satisfaction (Z) but not significant. This result is shown by a negative path coefficient of -0.042 with $\mathrm{T}$ - statistic $=0.328$ (T-statistic < 1.96). These results show that hypothesis-4 (H4): caracteristic (X2) has effect on saticfaction isn't proven empirically. Based on these results can be stated that the higher the characteristic the employees, the employee saticfaction isn't increasing directly.

\section{Hypothesis 5}

Education and training (X3) has a positive and significant effect on performance (Y). This result is shown by a positive path coefficient of 0.454 with $\mathrm{T}$ - statistic $=3.224$ (T-statistic > 1.96). These results show that hypothesis-5 (H5): Education and training (X3) has effect on performance proven empirically. Based on these results can be stated that the higher the Education and training the employees, the employee performance is increasing directly.

\section{Hypothesis 6}

Education \& training (X3) has a negative effect on satisfaction (Z) but not significant. This result is shown by a negative path coefficient of -0.018 with T- statistic $=0.141$ (T-statistic < 1.96). These results show that hypothesis-6 (H6): education \& training (X3) has effect on saticfaction isn't proven empirically. Based on these results can be stated that the higher the education \& training the employees, the employee saticfaction isn't increasing directly.

\section{Hypothesis 7}

Performance $(\mathrm{Y})$ has a positive and significant effect on satisfaction $(\mathrm{Z})$. This result is shown by a positive path coefficient of 0.821 with $\mathrm{T}$ - statistic $=5.323$ ( $\mathrm{T}$ - statistic $>1.96)$. These results show that hypothesis-7 (H7): performance $(\mathrm{Y})$ has effect on satisfaction proven empirically. Based on these results can be stated that the higher the Performance the employees, the employee satisfaction is increasing directly.

\section{Hypothesis 8}

Performance (Y) is not able to mediate positively on the indirect effect of Competence (X1) on satisfaction (Z). This result is shown from the mediation test conducted, it appears X1 -> Y $\rightarrow \mathrm{Z}$ effect have not a significant value, so So the performance variable is not able to mediate the relationship between the two variables.

\section{Hypothesis 9}

Performance $(\mathrm{Y})$ is able to mediate positively on the indirect effect of characteristic (X2) on satisfaction (Z). This result is shown from the mediation test conducted, Visible effects of significant indirect and direct effect coefficient in changing direction, then the performance variables mediate the relationship between both variables is suppression mediation.

\section{Hypothesis 10}

Performance (Y) is able to mediate positively on the indirect effect of Education (X3) on satisfaction (Z). This result is shown from the mediation test conducted, Visible effects of significant indirect and direct effect coefficient in changing direction, then the performance variables mediate the relationship between both variables is suppression mediation. 


\section{CONCLUSION}

Competency-based HR management is a must, as an approach that is considered the most urgent by emphasizing that the human element is the main element of organizational success. However, organizations to be able to provide quality civil servants to support the achievement of goals and objectives of organizations with high performance standards need to continue to improve MTU and the quality of their human resources. In addition, the competencies possessed by each employee individually can support the implementation of the organization's vision and mission through the strategic performance of government organizations.

In this study with the title under study, namely: Competency Determination, Individual Characteristics, Education and Training on Job Satisfaction through Employee Performance at the Karimun Regency Human Resources Development Agency, all the variables studied are indirectly significant through performance so that they can affect satisfaction.

\section{REFERENCES}

Afandi, P. (2018). Manajemen Sumber Daya Manusia (Teori, Konsep dan Indikator). Riau:

Zanafa Publishing. Alabi, Goski., \& Alabi, J. (2014). Understanding the Factors that

Influence Leadership Effectiveness of Deans in Ghana. JHEA/RESA Vol. 12, No 1 ,2014, pp. 111132.

Arikunto., \& Suharsimi. (2014). Prosedur Penelitian Suatu Pendekatan Praktik. Jakarta: Rineka Cipta

Bungin, B. (2011). Penelitian Kualitatif. Jakarta: Kencana Predana Media. Group. Casimir,

Handoko, T., \& Hani. (2011). Manajemen Personalia dan Sumberdaya Manusia. Yogyakarta: Penerbit BPFE.

Hasibuan., \& Malayu S.P (2013). Manajemen Sumber Daya Manusia. Jakarta PT. Bumi Aksara.

Hersona., Sonny., \& Sidharta, I. (2017). Influence of Leadership Function, Motivation And Work Discipline On Employees' Performance. Journal of Applied Management (JAM) Volume 15 Number 3, September 2017: 528-537.

Ilham, R. N., Sinaga, S., Putri, D. E., Sinta, I., \& Fuadi, F. (2021). EFEK DARI LEVERAGE DAN UKURAN PERUSAHAAN DALAM MEMENGARUHI TINGKAT PROFITABILITAS. JURNAL ILMIAH EDUNOMIKA, 5(02).

Ilham, R. N., Sadalia, I., Irawati, N., \& Sinta, I. (2022). Risk And Return Model of Digital Cryptocurrency Asset Investment In Indonesia. Al Qalam: Jurnal Ilmiah Keagamaan dan Kemasyarakatan, 16(1), 357-376.

Khaddafi, M., Subrata, H., Apriyanto, E., Iqbal, M., \& Darmawan, W. (2022). PENGENALAN DASAR PENGOPERASIAN KOMPUTER PADA ANAK USIA DINI. JATIMIKA: Jurnal Kreativitas Mahasiswa Informatika, 2(3).

Liyas, N.J. (2017). Pengaruh Kepemimpinan Terhadap Disiplin Kerja Karyawan pada PT. Bank Syariah Mandiri. JEBI (Jurnal Ekonomi dan Bisnis Islam)-Volume 2, Nomor 2, JuliDesember 2017: 121-129.

Luthans, F. (2014). Organization Behavior. New York: McGraw Hill International. Mangkunegara, A.A., \& Anwar, P. (2012). Manajemen Sumber Daya Manusia. Bandung: PT. Remaja Rosdakarya.

Santoso, J. T., Ginantra, N. L. W. S. R., Arifin, M., Riinawati, R., Sudrajat, D., \& Rahim, R. (2021). Comparison of Classification Data Mining C4. 5 and Naïve Bayes Algorithms of EDM Dataset.

Satrio, E. D., \& Khaddafi, M. (2021). DETERMINATION OF TRANSFORMATIONAL LEADERSHIP, SELF EFFICACY AND WORK RESPONSIBILITIES WITH MOTIVATION AS VARIABLE OF MEDIATOR ON THE PERFORMANCE OF GENERAL BUREAU OFFICER OF PROVINCIAL SECRETARIAT OF RIAU ISLANDS 
Volume 2 Issue 1 (2022)

DETERMINATION OF COMPETENCE, INDIVIDUAL CARACTERISTICS, EDUCATION AND TRAINING ON SATISFACTION WORKING THROUGH THE PERFORMANCE OF EMPLOYEES IN HR DEVELOPMENT AGENCY KARIMUN DISTRICT

DOI: https://doi.org/10.54443/ijerlas.v2i1.144

USING SEM PLS. Zona Manajerial: Program Studi Manajemen (S1) Universitas Batam, $10(1), 42-55$. 